\title{
Protagonists students in the Coexistence School ${ }^{1}$
}

\author{
Telma Pileggi Vinha (PQ), Fayza Maria Khalifa (IC).
}

\begin{abstract}
The initiative that was investigated here is the proposal of protagonists students - students that offer a support to their peers in many aspects of everyday life, forming support teams, mentoring, mediation, among others. These students also go on to be responsible for respectful coexistence, through responsibilities and functions that were previously restricted only to adults. This proposal has been carried out mainly in Spain and it is still not found in Brazilian schools.Based on this, there was conducted a literature review of academic publications in the period between 2000-2014 that addressed the protagonists students, as well as it was based on studies a description of how the school can implement a proposal in which the students can effectively participate improving coexistence school.
\end{abstract}

Key words: student protagonist, relationship in school life, support teams.

\section{Introduction}

Studies indicate that often the school actors face situations of conflict as aggression, violence, indiscipline, transgressions, bullying or incivilities that are perpetuated in school, disrespect and lack of citizenship. Students, employees and professionals of education are affected by this situation. No spaces for discussion and dialogue for the resolution of interpersonal conflicts or for learning democracy, children and adolescents do not develop trading strategies more assertive, fair and respectful. In this way, it is necessary the implementation in school of procedures that contribute to the reduction of violence, mediation of conflicts and the promotion of better relationship in school life.

\section{Results and Discussion}

Because the proposals are recent, there are few publications that investigate or describe them. Fifty-five publications were found: articles, books, chapters of books and manuals. Based on these studies, we describe the different types of support teams, their characteristics and performances at school and also the training process. The literature indicates that the development of this proposal helps to deal more constructively through support among peers in situations of conflict, bullying and cyberbullying, mediation of conflicts, learning problems and loneliness at school, promoting respect, solidarity and the strengthening of interpersonal relations among peers.

\section{Conclusions}

It is expected that this research will contribute to the training of teachers in the implementation of support teams in order to promote the role of youth in transforming respectful conflict environments.

\section{Acknowledgement}

A special thanks to my family, to my research advisor Telma Pileggi Vinha, to my undergraduate friends from Unicamp, to my colleagues from the Research Group on Moral Education - GEPEM and to $\mathrm{PIBIC/CNPq}$.

\footnotetext{
'This study integrates research "Seeking ways to promote respectful coexistence in the classroom every day," coordinated by Dr. Telma Vine and with support from Lemann and Itaú BBA Foundation.
}

TORREMORELL, Carme Boqué. Guía de mediación escolar. Sevilla: Octaedro, 2002.

SERRANO, G. e GUZMÁN, Mã.V. Aprender a convivir Madrid: Narcea, 2011.

TORREGO, Juan Carlos. La ayuda entre iguales para mejorar la convivencia escolar. Madrid: Narcea, 2012.

DURAN, David.Tutoria: Aprendizagem entre iguais. Americana: Artmed, 2007.

ARRÓ, M., VILLANUEVA, L., y TRAVER, J. El alumnoamigo: un sistema de ayuda entre iguales. Ponencia presentada en las Jornadas de Fomento de la Investigación. Universitat Jaume I, 2006.

FERNÁNDEZ, I., y ORLANDINI, G. La ayuda entre iguales. Cuadernos de Pedagogía, 2001, 304, 97-100. 